\title{
Autosomal dominant optic atrophy, classic form
}

INSERM

\section{Source}

INSERM. (1999). Orphanet: an online rare disease and orphan drug data base. Autosomal dominant optic atrophy, classic form. ORPHA:98673

Autosomal dominant optic atrophy (ADOA) is one of the most common forms of hereditary optic neuropathy (see this term) characterized by progressive bilateral visual loss during the first decade of life, associated with optic disc pallor, visual field and color vision defects. 